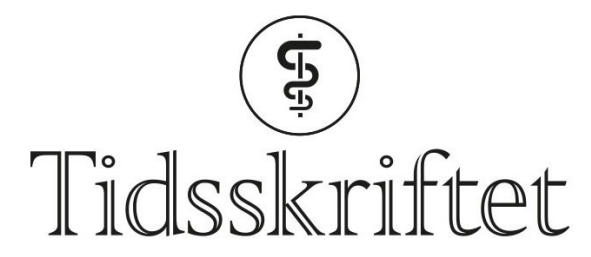

DEN NORSKE LEGEFORENING

\title{
Oksygen i forkledning
}

SPRÅKSPALTEN

\section{ØYVIND STOPLE SIVERTSEN}

E-post: oyvind.stople.sivertsen@tidsskriftet.no

Øyvind Stople Sivertsen er allmennlege i spesialisering og medisinsk redaktør i Tidsskriftet.

Lavgradig oksygenbehandling gis ofte gjennom nesen. Men dersom man tar ordinasjoner fra norske leger bokstavelig, kan det gi overraskende resultater.

Mange akuttmedisinske tilstander bedres dersom pasienten behandles med oksygen. En ofte brukt anbefaling er å gi oksygen 2-4 l/min via nesen. De siste årene har jeg lagt merke til flere ulike betegnelser for utstyret som benyttes i denne typen oksygenbehandling (fig 1).

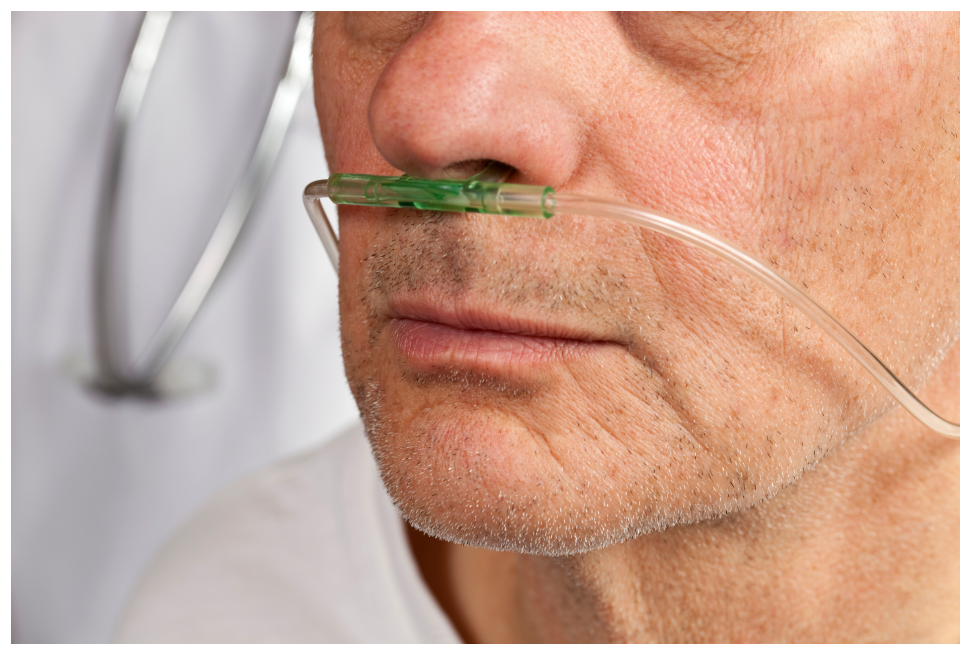

Figur 1 Oksygen via nesen. Foto: Johnrob/iStock.

Oksygen gitt via nesegrime høres ofte i akuttsettinger. Brillekateter brukes også. Eller hva med nesebrille? Dette ordet ble nylig brukt i et innsendt manus til Tidsskriftet, og har også stått på trykk hos oss tidligere (1).

Et raskt bildesøk på «nesegrime» og «nesebrille» avdekker henholdsvis dressurutstyr for hund (fig 2) og klassisk spionforkledning med bart, briller og buskete øyebryn (fig 3 ). 


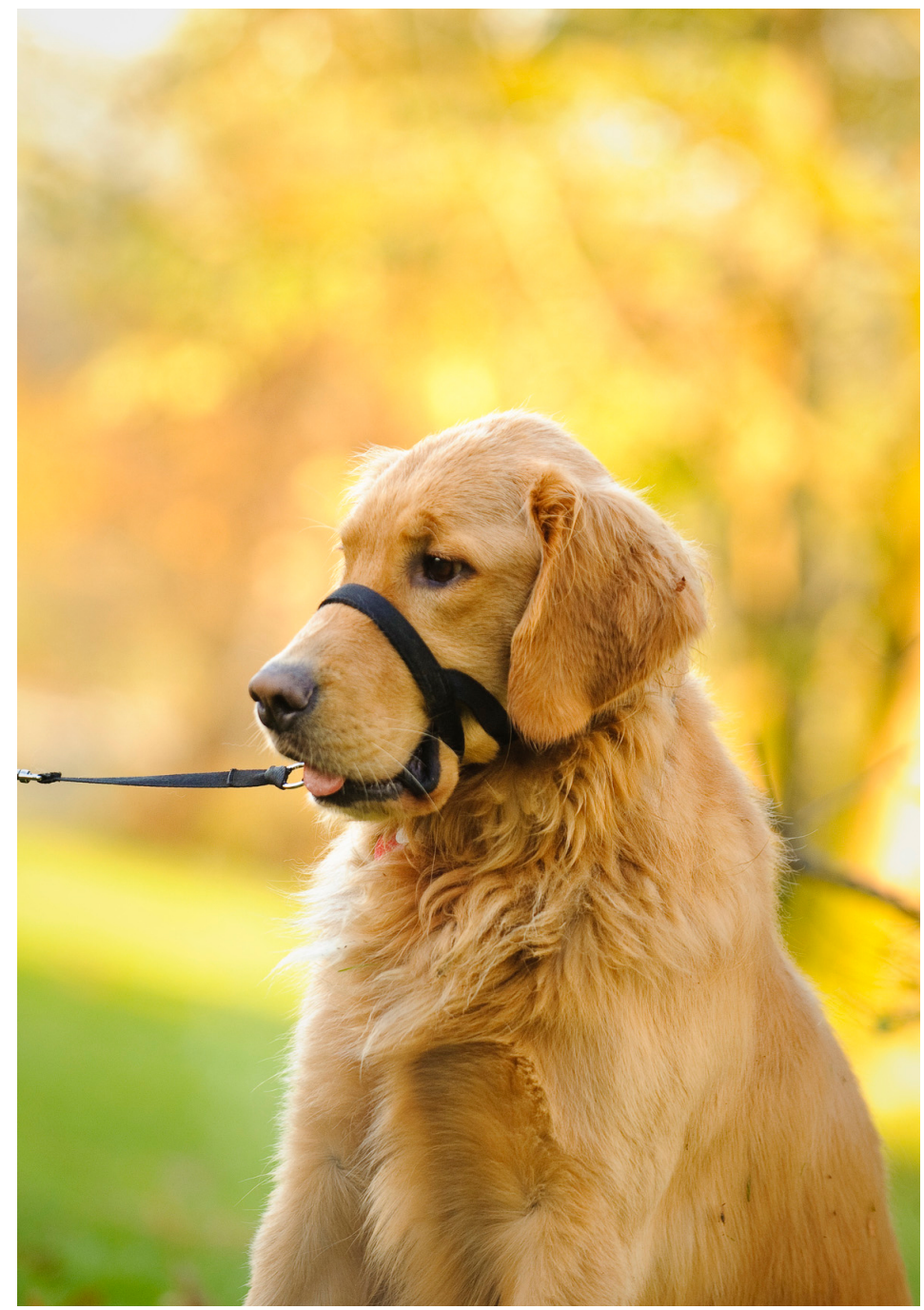

Figur 2 Nesegrime. Foto: horsesdogscats/iStock.

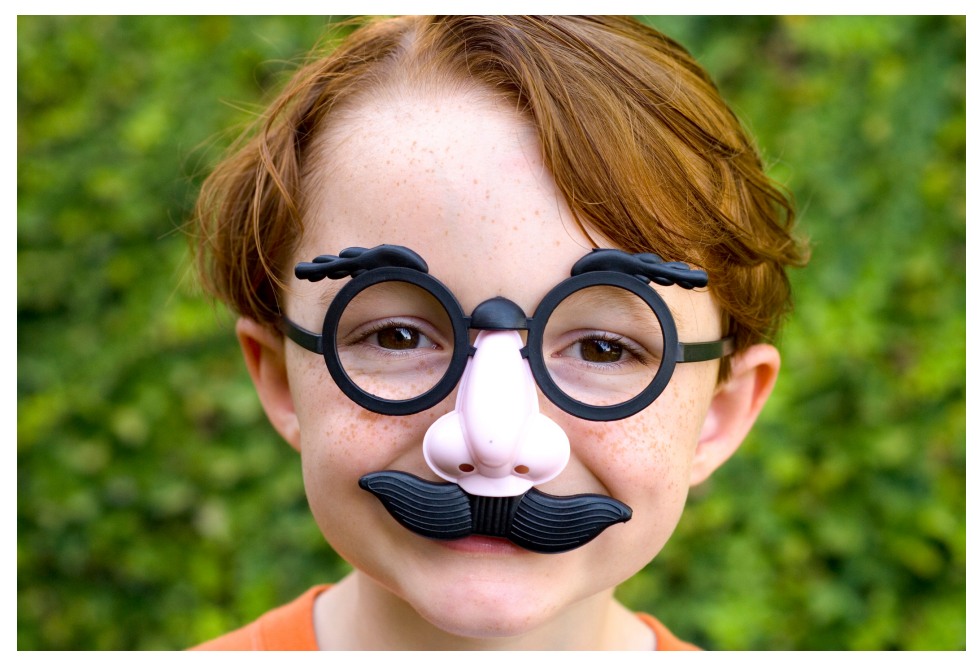

Figur 3 Nesebrille. Foto: funwithfood/iStock.

\section{Seks muligheter}

I Tidsskriftets nettutgave finner jeg fem termer for dette akuttmedisinske utstyret, her nevnt etter avtagende frekvens: nesekateter (brukt 18 ganger), nesegrime (3 ganger), brillekateter (2 ganger), nesebrille (1 gang) og nese-brille-kateter (1 gang).

I Nasjonalbibliotekets digitalarkiv bokhylla.no er det også ordet nesekateter som gir klart flest treff. Det finnes som oppslagsord i Samlagets medisinske ordbok, som viser til den engelske termen nasal catheter (2). I allmennordbøker finnes både nesegrime $(3,4)$ og nesekateter (5). 
I akuttmottaket ved Akershus universitetssykehus fant jeg et sjette alternativ. Her finnes pakninger med teksten oksygenbrille. Dette er ikke et oppslagsord i ordbøkene, ei heller har ordet funnet veien til Tidsskriftets spalter - før nå.

Selv om det antakelig er lite sannsynlig at sykepleierne finner frem forkledning eller hunderemedier i en akuttsetting, tror jeg det er fornuftig å holde seg til termen nesekateter i forbindelse med oksygenbehandling. Det virker mer naturlig å la kateter - et ord som er godt etablert i medisinen - være det produktive elementet her i stedet for brille eller grime, som gir andre og presumptivt lite tiltrekkende assosiasjoner, blant annet til husdyrhold.

\section{LITTERATUR:}

1. Bretthauer M. Best med kontinuerlig overtrykk ved postoperativ hypoksemi. Tidsskr Nor Lægeforen 2005; $125: 857$.

2. Nasekateter. I: Øyri A. Norsk medisinsk ordbok. 9. utg. Oslo: Samlaget, 2011: 729.

3. Nesegrime. I: Det norske akademis ordbok. https://www.naob.no/ordbok/nesegrime (26.8.2018).

4. Nesegrime. I: Kirkeby P-E. Den store norske bokmålsordboka. Oslo: Kagge, 2014: 1085.

5. Nesekateter. I: Kirkeby P-E. Den store norske bokmålsordboka. Oslo: Kagge, 2014: 1085.

Publisert: 10. oktober 2018. Tidsskr Nor Legeforen. DOI:10.4045/tidsskr.18.o691

(C) Tidsskrift for Den norske legeforening 2020. Lastet ned fra tidsskriftet.no 